\title{
The Istanbul Canal or New \\ Bosphorus
}

\author{
Arestakes Simavoryan
}

Published online: June 18, 2020

Publisher: Orbeli Center ${ }^{1}$

Currently, 24 projects related to infrastructure (bridges, highways, airports, railway communication networks, ports, tunnels), energy and military industry are in various stages of implementation in Turkey. 8 of these are mega-projects worth $\$ 5$ to $\$ 28$ bil. The other projects in total are estimated to cost more than $\$ 220$ bil. $^{2}$ The largest and most expensive in the history of the Republic of Turkey, Southeastern Anatolia Project of Social-Economic Significance valued $\$ 28$ bil., leads the list of mega-projects. Until now, large investments have been made in education, health, transport and energy fields. Other major projects include the Sinop and Akkuyu Power Plants ${ }^{3}$, with $\$ 22$ bil. and $\$ 20$ bil. respectively. Among these projects is Erdogan's "craziest projects" (as is often referred to by the Turkish press), the construction of the Istanbul Canal connecting the Mediterranean Sea to Black Sea and is estimated at $\$ 15-20$ bil.

\section{The Canal and Adjacent Infrastructures}

President Erdogan first spoke about the construction of the canal in 2011, at a conference in Istanbul dedicated to the various infrastructures projects of Turkey. According to Erdogan, the canal is an important strategic project, which will contribute to the unprecedented development of the economy by changing the capital's direction ${ }^{4}$. It was announced that the canal will be finished in 2023, on the 100th anniversary of the Republic of Turkey ${ }^{5}$. Initially the Istanbul Canal was planned to be constructed on the outskirts of Silivri. However, public criticism about the project (especially by environmentalists), made the Government change the initial idea of the sea route. In February 2016, the new route had to pass more towards the Westthan the originally selected route ${ }^{6}$.

Former Minister of Transport and Infrastructure Ahmet Arslan announced in 2018,

\footnotetext{
${ }^{1}$ Source: https://orbeli.am/en/post/476/2020-06-18/The+Istanbul+Canal+or+New+Bosphorus.

2 Türkiye'nin mega projeleri: Sifirdan rekora. http://optamin.com/turkiyenin-mega-projeleri.

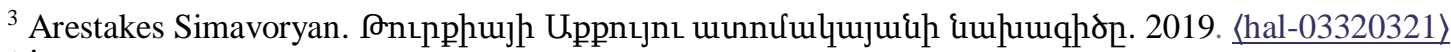

4 İşte Erdoğan'ın çılgın projesi, (27.04.2011), https://www.milliyet.com.tr/siyaset/iste-erdoganin- cilgin-projesi1382967

$\frac{13}{5}$ It's known from the history, that in 1550, Ottoman Kanuni Sultan Suleyman I wanted to dig a canal parallel to the Bosphorus. Famous architects Mimar Sinan and Nicolas François worked on that project. However, the resources required for the project weren't sufficient, Kanal İstanbul nedir? Güzegahı açıklanan Kanal İstanbul Projesi, (15.01.2018), https://www.milliyet.com.tr/gundem/kanal-istanbul-nedir-guzegahi-aciklanan-kanalistanbul-projesi-2591192

${ }^{6}$ Turkey plans new major waterway to bypass Bosporus, (27.04.2011), https://www.sandiegouniontribune.com/sdut-turkey-plans-new-major-waterway-to-bypass-bosporus-2011apr27story.html.
} 
that the canal will have $45 \mathrm{~km}$. length with a width of $400-600 \mathrm{~m}$. and a depth of $25 \mathrm{~m} .{ }^{7}$. However, completely different sizes are given on the website of the Istanbul Canal launched by the Public Relations Department of the Office of the President of Turkey in 2020. In particular, the length and depth of the canal remain the same, but the width has a reduced amount from $400 \mathrm{~m}$. to $275 \mathrm{~m}$. However, according to the website, the size of the canal may change, given regional developments that will benefit Turkey's geopolitical and strategic priorities ${ }^{8}$.

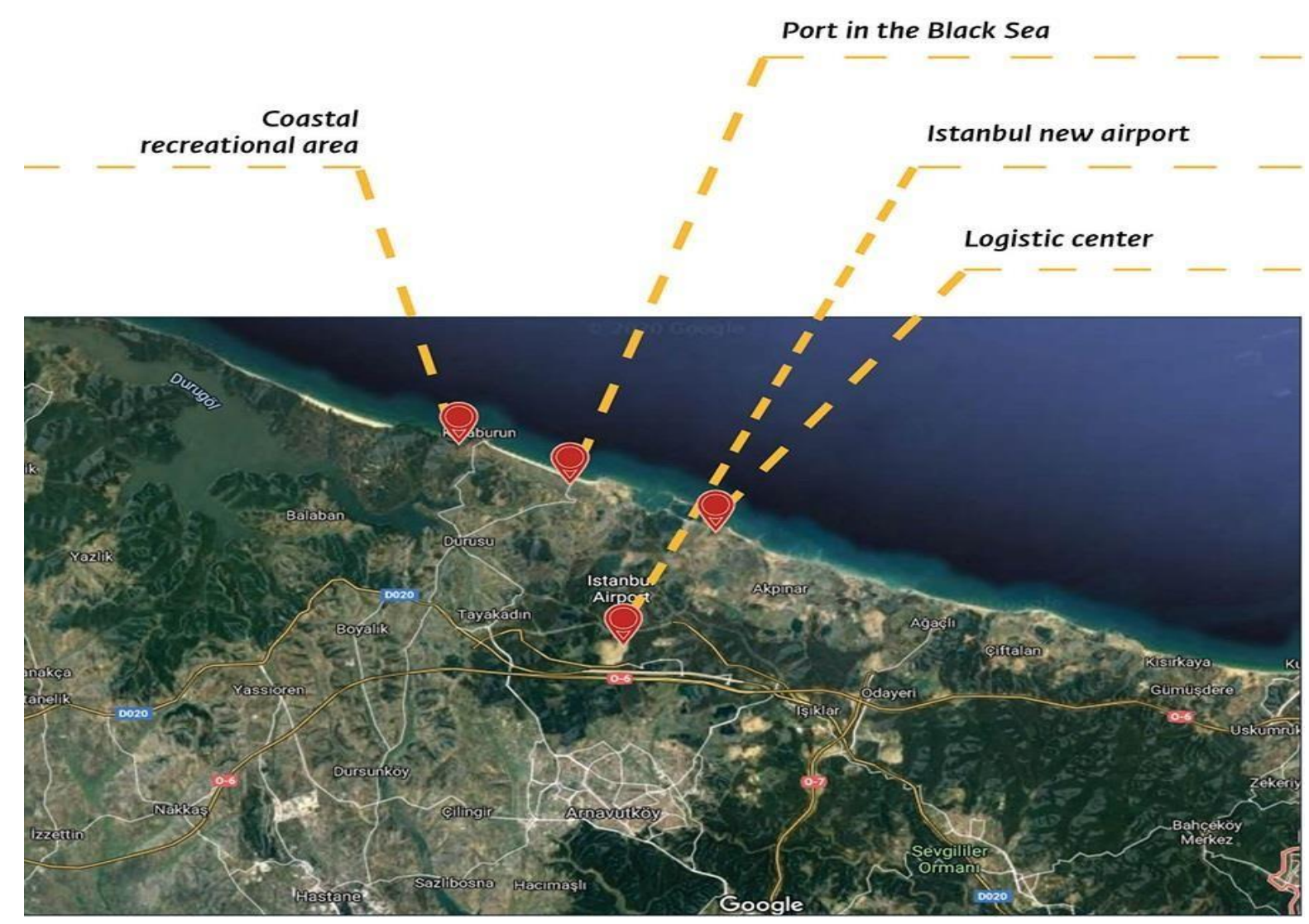

The canal will be built in parallel to the Bosphorus and in fact will be an alternative: it will pass through Kucukcekmece-Sazlidere-Durusu districts. 160 different types of cargo ships (including oil tankers), that is about 58,400 ships a year will pass through this waterway daily. As a comparison, while only 25000 ships are actually allowed to pass through the Bosphorus, 41,112 cargo ships $(54,880 \text { in 2006) })^{9}$ passed through the Bosphorus Strait (Istanbul Strait in Turkish) in 2019.

According to some estimates, the number of ships passing through the Bosphorus

\footnotetext{
7 İstanbul'un 19 ilçesi adalı olacak! 6 köprü ile birbirine bağlanacak!, (24.01.2018), https://www.hurriyet.com.tr/ekonomi/istanbulun-19-ilcesi-adali-olacak-6-kopru-ile-birbirine-baglanacak40719953

${ }^{8}$ Kanal İstanbul Projesinin Kesit ve Boyutları. https://www.kanalistanbul.gov.tr/tr/hersey/kanal-istanbulprojesinin-kesit-ve-boyutlari

${ }^{9}$ In recent years, shipping through this strait decreased by $25 \%$, but the weight of cargo has increased. Yillara Göre Karşılaştırma Tablosu, https://atlantis.udhb.gov.tr/istatistik/gemi_gecis.aspx
} 
will exceed 80,000 per year by 2070 , creating an additional workload ${ }^{10}$. The number of cargo passing through the Bosphorus will most likely be reduced. Thus the main and primary goals of the construction of the canal is to reduce the flow of ships passing through the Bosphorus. However, by increasing ships through the route of the Bosphorus, it's possible that the "Istanbul" canal will become a congested new sea route.

The next goal is to minimize environmental threats. Due to being overloaded, 9 major disasters occurred in the Bosphorus Strait between 1960-2019. They were accompanied by human losses and with financial losses amounting to about $\$ 1.3$ bil. ${ }^{11}$. According to the Minister of Transport and Infrastructure C. Turhan, in the first stage, will have a net income of $\$ 1$ bil. from cargo ships passing the canal and $\$ 5$ bil. in $2050^{12}$.

However, the project doesn't end with theconstruction of the canal alone. Residential complexes will be built on an area of 38 thous. hectares $(26,500$ hectares based on the other data) along the two banks of the artificial canal. Thanks to modern transport infrastructure, including subway and high-speed trains, the newly formed city with 500 thous. population will be connected to other regions ${ }^{13}$.

The population of the city stretching on both sides of the canal will be moved especially from the areas where the residential buildings have been assessed as dangerous ${ }^{14}$. Instead of the 10 previously planned bridges, which will provide land connection over the canal, it is now planned to build 6 bridges, 5 for cars and 1 for highspeed trains. There will also be 3 tunnels, 2 for subway and 1 for underwater railway ${ }^{15}$.

Furthermore, it's envisaged to build cultural, educational, healthcare and business centers, modern architectural style skyscrapers and hotel complexes. It's also planned to build eco- tourism, medical-resort tourism, technology development, local and international logistic zones and ports. In particular, the newly created infrastructure will include a coastal recreational area, a naval (industrial) port for cargo ships and a logistic center. Moreover, in terms of location, the latter two are bordering the New or Third Istanbul International Airport, which started to operate since October 2018. The report on the construction of the Istanbul Canal notes that yacht and container ports will be built on the shores of Lake Kucukcekmece, part of the Marmara Sea ${ }^{16}$.

In 2021, at the entrance of the Bosphorus Strait, by the Sea of Marmara in Yenikap, a new cruise port will be put into operation, which will be integrated into the Istanbul Canal and the new airport ${ }^{17}$. Except for the canal (\$15-20 bil.) and the new airport ( $€ 10.5$ bil.), the other above mentioned infrastructure will require additional investment, for the

\footnotetext{
${ }^{10}$ Barış Şimşek, Boğaz'dan 13 kat daha güvenli, (03.02.2020).

https://www.sabah.com.tr/galeri/ekonomi/bogazdan-13-kat-daha-guvenli

11 İnfografikler, https://www.kanalistanbul.gov.tr/tr/infografik

12 Kanal İstanbul Projesi’ni 2026 gibi tamamlamış olacağız, (13.01.2020), https://www.milliyet.com.tr/gundem/kanal-istanbul-nedir-guzegahi-aciklanan-kanal-istanbul-projesi-2591192

${ }^{13}$ Nüfus ve Yeni Yerleşim Alanı, https://www.kanalistanbul.gov.tr/tr/hersey/nufus-ve-yeni-yerlesim-alani.

14 Özetle Kanal İstanbul Projesi, (02.01.2020), https://www.milliyet.com.tr/gundem/ozetle-kanal-istanbulprojesi-kanal-istanbul-ihalesi-kanal-istanbul-maliyeti-ve-kanal-istanbul-ced-raporu-hakkinda-bilinmesigerekenler-6114038

${ }^{15}$ Kanal İstanbul raporu, “193 sayfa” ile özetlenerek İBB meclisine sunuldu, (15.03.2020),

https://www.istanbultakipte.com/haberler/cevre/kanal-istanbul-raporu-193-sayfa-ile-ozetlenerek-ibb-meclisinesunuldu.html

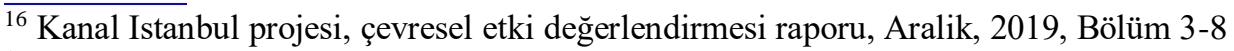

${ }^{17}$ Канал Стамбул - будущий туристический центр Турции, http://fellowtraveler.ru/kanal-stambul-budushhij$\underline{\text { turisticheskij-centr }}$
} 
construction of which the private and public sectors will be involved. An international consortium of investors will be created, which is often done for large projects. Foreign direct investment flow is also expected, especially from Arab countries ${ }^{18}$.

The World Bank, the European Bank for Reconstruction and Development, the Islamic Development Bank and the Japan International Cooperation Agency, which currently finance many projects aimed at creating and developing various infrastructures in Istanbul, will probably be interested. Currently the South Korean SK Engineering and Construction Company expressed a wish to participate in the construction of the Istanbul canal. This company has implemented a number of projects in Turkey, such as the Eurasia Underwater Tunnel, which connects the European and Asian shores of Istanbul, the third bridges of Yavuz Sultan Selim and the Bosphorus, structures of energy significance, such as the suspension bridge Çanakkale 1915, the construction of which is currently ongoing ${ }^{19}$.

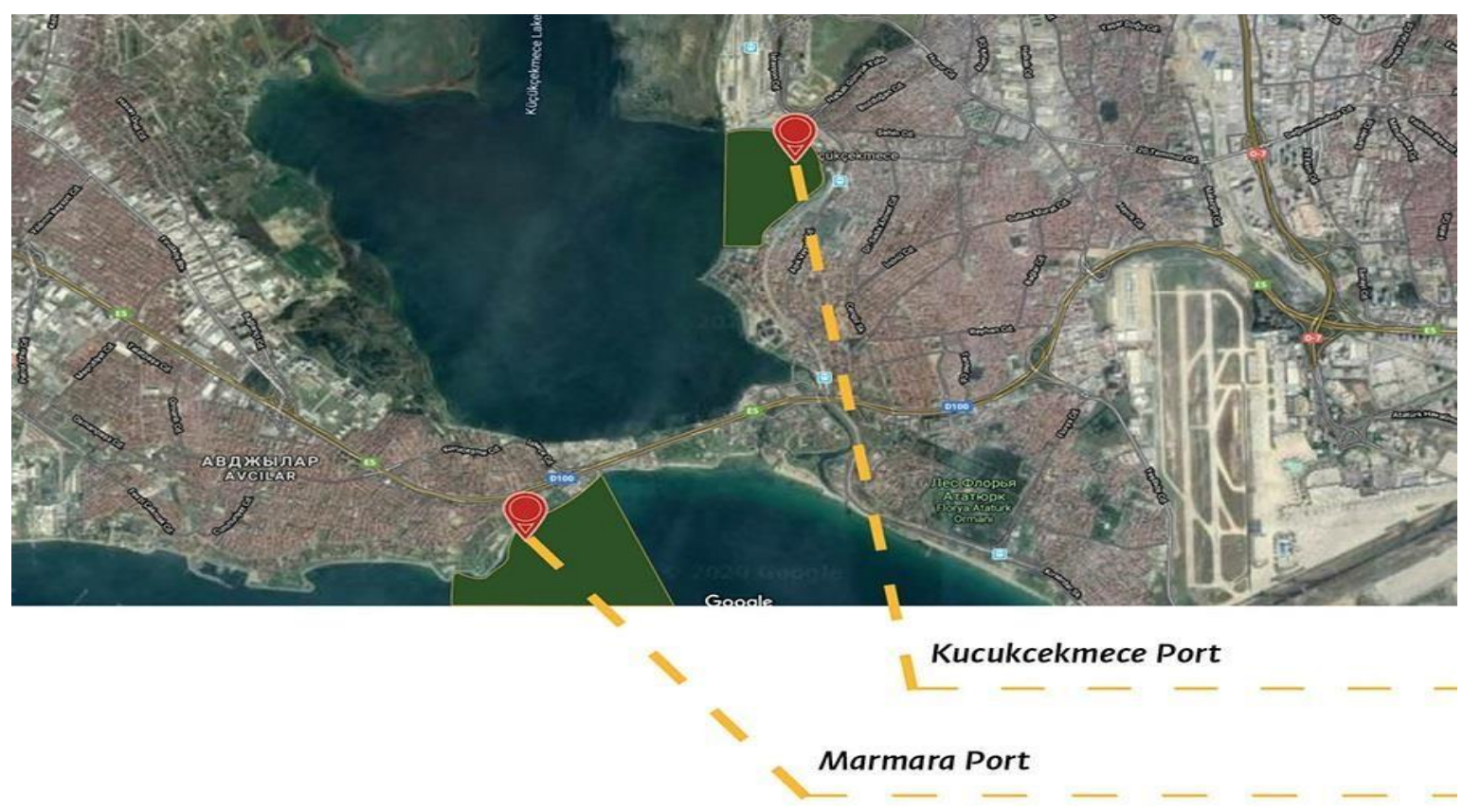

One of the key issues of the construction of the canal is how Turkey is ready to implement such an ambitious project. According to analysts, Turkey neither has the experience in conducting large-scale canal work, nor has a corresponding professional staff.

This was also taken into account by the Turkish Government, which began negotiations with the Panamanian authorities. According to the agreement signed between Ministries of Panama's navigation and Turkish Transport in 2016, the parties undertook a platform for cooperation to exchange administrative and technical knowledge and work experience, which are closely related to the construction and management of canals. According to the agreement, the construction of the Istanbul Canal will be supported by professional groups that have expanded the Panama $\mathrm{Canal}^{20}$.

\footnotetext{
${ }^{18}$ Sinan Ulgen, Choppy Waters For Turkey's Latest Megaproject, (21.01.2020), https://www.bloomberg.com/opinion/articles/2020-01-21/canal-istanbul-choppy-waters-for-erdogan-s-latestmegaproject.

${ }^{19}$ South Korean SK plans to partake in Kanal Istanbul, (10.05.2018), https://www.dailysabah.com/business/2018/05/10/south-korean-sk-plans-to-partake-in-kanal-istanbul

${ }^{20}$ Emin Özgönül, Kanal İstanbul'a Panama modeli, (07.05.2017),

https://www.sozcu.com.tr/2017/ekonomi/kanal-istanbula-panama-modeli-1835664/
} 


\section{Ecological Issues}

There are environmental and seismic concerns in the discussions on the construction of the canal as well. According to experts, the canal can completely change the ecosystem of the region, endangering the life support systems of Istanbul. In particular, it will affect the quality and environment of agricultural lands, increase the risk of earthquakes ${ }^{21}$.

Other experts believe it will contribute to the extinction of rare plant species. Furthermore, the mixing of the two seas will change the chemical composition, which can also lead to the extinction of marine animals ${ }^{22}$. According to some forecasts, coastal areas around the Sea of Marmara will be at the risk of flooding ${ }^{23}$. It was decided to partially close the Sazlidere reservoir during the implementation of the project, which will later be part of the Istanbul Canal. This is also a serious problem, as the reservoir is the main source of fresh water in the European part of Istanbul ${ }^{24}$.

Combining different environmental assessments and forecasts, it should be noted that according to environmentalists, it will be a problem not only for Turkey, but for all neighboring countries, as the construction of the canal can have a negative impact on the ecosystem of the whole region. On March 8, 2020, Erdogan announced again that all necessary geological and hydrological research had been carried out and the danger of earthquakes was taken into account during the design of the canal. More than 200 specialists and international experts from 11 Turkish universities and 34 scientific branches took part in them ${ }^{25}$.

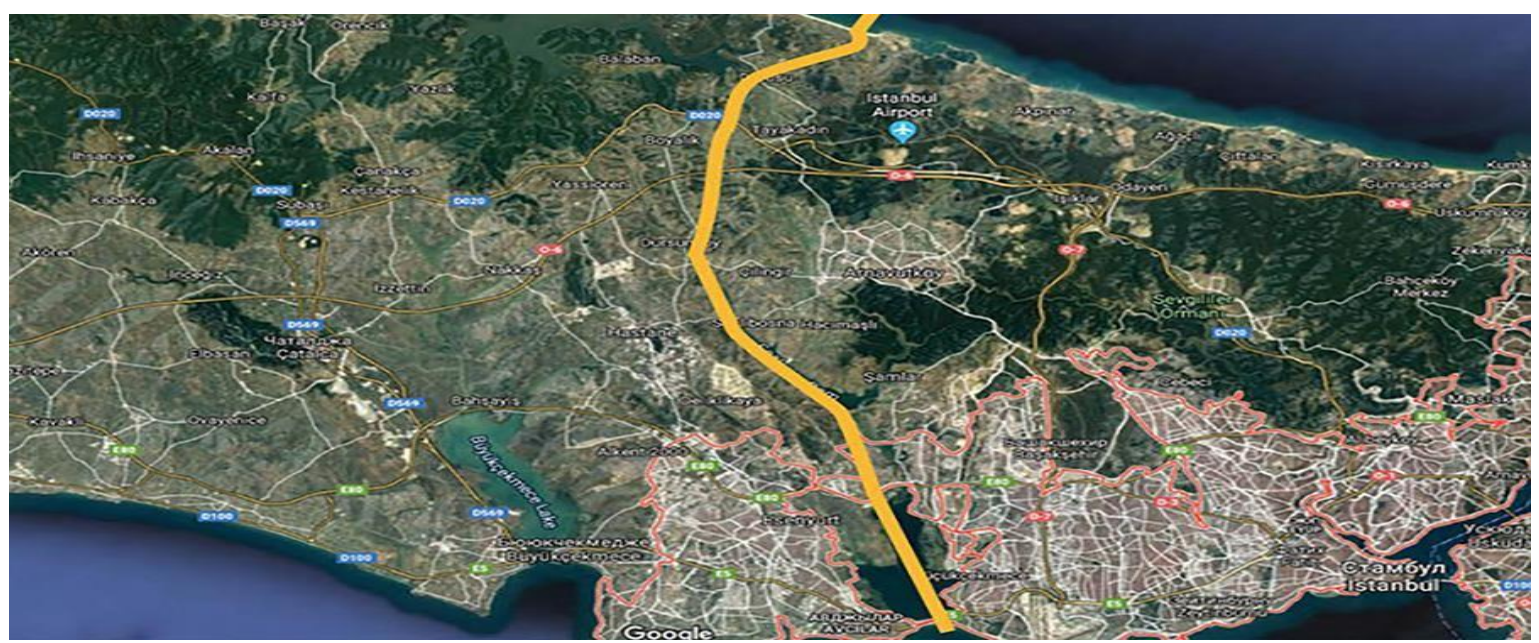

\section{The direction of construction of the Istanbul Canal}

\footnotetext{
${ }^{21}$ Cemal Gökçe, İstanbul Kanal Projesi Neden Yapılmamalıdır? Türkiye Mühendislik Haberleri, Sayı: 490 61/2016-2, s. 60-61.

${ }^{22}$ Ertuğrul Günay, Canal Istanbul project casts doubts on Montreux Convention, (23.12.2019), https://ahvalnews.com/montreux-convention/canal-istanbul-project-casts-doubts-montreux-convention. Dicle Baştürk Özarslan, Uluslararası politika açısından Kanal İstanbul: 310 milyon insan için bir risk, (14.10.2018), https://t24.com.tr/haber/uluslararasi-politika-acisindan-kanal-istanbul-310-milyon-insan-icin-bir-risk,722851.

${ }^{23}$ Sena Yaşar, Jeoloji mühendislerinden uyarı: 'Marmara'da sahil kalmaz', (23.01.2020), https://www.cumhuriyet.com.tr/haber/jeoloji-muhendislerinden-uyari-marmarada-sahil-kalmaz-1715791.

${ }^{24}$ Kanal İstanbul ÇED raporu onaylandı! Sazlıdere Barajı kapatılıyor, (17.01.2020), https://www.kayabasimahallesi.com/haber/2950/kanal-istanbul-ced-raporu-onaylandi-sazlidere-barajikapatiliyor.html.

25 Эрдоган анонсировал тендер на проект канала «Стамбул» в обход Босфора, (08.03.2020), https://ria.ru/20200308/1568328983.html.
} 


\section{The Status of the Canal}

The voyage through the Bosphorus and Dardanelles is regulated by the Montreux Convention on the Status of the Straits (signed in 1936), which is controlled by Turkey. The convention allows the free movement of commercial vessels of all countries through the straits both in peacetime and during the war. In case of war Turkey may allow or prohibit the navigation of warships through the straits ${ }^{26}$.

As you know, navigation on the Bosphorus-Dardanelles is regulated by the Montreux Convention on the Status of the Straits (signed in 1936), which is controlled by Turkey. The Convention allows the free movement of merchant ships of all countries through these straits, both in peace and in time of war. In case of war or threat, Turkey can allow or prohibit the movement of warships of any country through the straits ${ }^{27}$.

According to retired Deputy Admiral T. Erturk, the US is more dissatisfied with the Montreux Convention: "Black Sea is the only one on the planet, where American aircraft carriers cannot enter. Of course, they want to change the balance of power. Thus, for maintaining stability, we must adhere to the Montreux Convention" 28 .

Experts believe that Washington has been trying to bypass the convention for years, and the Istanbul Canal is a good opportunity for the United States to de facto establish itself in the Black Sea. On this occasion, Mehmet Ali Guler, a columnist for the opposition Cumhuriyet newspaper, reminded NATO Secretary General Jens Stoltenberg "You are not in the Black Sea at all. The Black Sea has practically turned into a Russian Sea" Erdogan's call (2016), is a message to NATO and the United States to strengthen in the Black Sea. According to him the Istanbul Canal project initiated by the Justice and Development Party, will allow the USA to easily achieve this goal, which will be a "state suicide" for Turkey ${ }^{29}$.

Some experts believe that Turkey tries to extend the Montreux Convention to the Istanbul Canal or to revise the agreement in its favor ${ }^{30}$. However, in 2011, Erdogan stated that the canal doesn't contradict the Montreux Convention, but it doesn't have anything to do with it, asthe control of the canal is exclusively Turkey's sovereign right ${ }^{31}$.

Turkey will regulate the passage of ships in times of war and peace through the Istanbul Canal by national law, which was quoted by Turkish Foreign Minister Mevlut Cavusoglu ${ }^{32}$. According to some researchers, the convention will not apply to the new

\footnotetext{
${ }^{26}$ Габриелян Айк, Турция: Стамбульский канал и Конвенция Монтрё, (28.02.2017), http://www.iimes.ru/?p=32948. Hayk Gabrielyan, On the Construction of the Istanbul Canal in Turkey, (26.03.2018), http://noravank.am/arm/articles/detail.php?ELEMENT_ID=16532., Ольга Будник, Канал «Стамбул»: невозможно возможный проект, (20.12.2019), https://www.ukrinform.ru/rubrictechnology/2842117-kanal-stambul-nevozmozno-vozmoznyj-proekt.html., Умбрасас А.P, Современное состояние и перспективы конвенции Монтрё 1936 г. о статусе проливов, Международный журнал прикладных наук и технологий «Integral» №3, 2019, с. 511-517.

${ }^{27}$ Конвенция Монтрё о статусе проливов. Досье, https://tass.ru/info/1418303.

${ }^{28}$ Hilmi Hacaloğlu, Kanal İstanbul Montrö Sözleşmesi’ni Tehdit Ediyor mu? (10 .01. 2020), https://www.amerikaninsesi.com/a/kanal-istanbul-montro-sozlesmesini-tehdit-ediyor-mu/5240735.html. ${ }^{29}$ Mehmet Ali Güller, Kanal İstanbul: NATO’ya Karadeniz yolu, (16.12.2019), http://cumhuriyet.com.tr/koseyazisi/1708425/kanal-istanbul-natoya-karadeniz-yolu.html.

30 Jennifer Hattam, Turkish Prime Minister Erdoğan's 'Crazy Project' for Istanbul: Building a Second Strait, (30.04.2011), https://www.treehugger.com/corporate-responsibility/turkish-prime-minister-erdoayans-crazyproject-for-istanbul-building-a-second-strait.html.

${ }^{31}$ Kanal Istanbul'dan 5 milyar dolar gelir beklentisi!, (18.05.2011), https://emlakkulisi.com/kanalistanbuldan-5milyar-dolar-gelir-beklentisi/73548.

${ }^{32}$ Nazlı Yüzbaşığlu, Dışişleri Bakanı Çavuşoğlu: Emekli büyükelçilerin Kanal İstanbul açıklaması siyasi bir
} 
canal, whereas Turkey will have new political and economic leverages ${ }^{33}$. Regardless of the official statements and comments, the legal status of the Istanbul Canal is still uncertain.

The next important issue is that according to the terms of the Montreux Convention of 1936, with some exceptions, is free of movement for commercial vessels when passing through the Straits of Bosphorus and Dardanelles ${ }^{34}$. While after the project of operation Istanbul Canal, commercial ships will have to pay.

It's hard to imagine, how Turkey would persuade ships to pass through Istanbul's paid canal, when there is the Montreux Convention that allows to travel through the Bosphorus Strait for free. Moreover, appropriate analysis and political predictions and diplomatic efforts will be made to ensure the strait is available free of use. Melis Alphan, the journalist of Hurriyet newspaper noted that this this crazy project does not promise anything good. According to the author, after billions of investments, if Russia, for example, refuses to use the toll sea route, what steps should Turkey take in that direction ${ }^{35}$ ? But the new canal will promise an increase in Turkey's role in controlling the flow of ships. So, professional discussions on the canal continue.

As we see, this is quite a difficult and ambitious project, which in addition to the canal, also envisages the creation of recreational resources, expensive transport, business and other infrastructure. In 2011, Erdogan announced that the canal will be ready in 2023. Meanwhile, the new term of the project, 2025-2026 is officially being discussed today, unless canal drilling begins in $2020^{36}$.

\section{Bibliography}

Türkiye'nin mega projeleri: Sıfirdan rekora. http://optamin.com/turkiyenin-megaprojeleri.

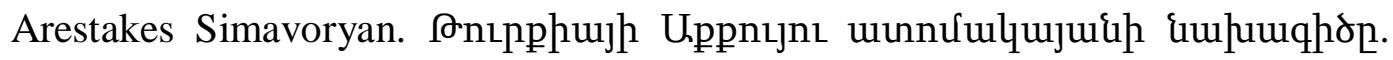
2019. 〈hal-03320321〉.

İşte

Erdoğan'ın çılgın projesi, https://www.milliyet.com.tr/siyaset/iste-erdoganin- cilgin-projesi1382967.

Kanal İstanbul nedir? Güzegahı açıklanan Kanal İstanbul Projesi, (15.01.2018), https://www.milliyet.com.tr/gundem/kanal-istanbul-nedir-guzegahi-

\footnotetext{
deklarasyondur, (02.02.2020), https://www.aa.com.tr/tr/politika/disisleri-bakani-cavusoglu-emeklibuyukelcilerin-kanal-istanbul-aciklamasi-siyasi-bir-deklarasyondur/1721885

${ }^{33}$ Feargus O'Sullivan, Could Istanbul's Protesters Halt Turkey's Controversial Canal Project? (04.06.2013), https://www.citylab.com/life/2013/06/could-istanbuls-protesters-halt-turkeys-controversial-canal-project/5787/. ${ }^{34}$ Charging is made only for the use of sanitary, rescue and other services, and for the double passage of ships through the Dardanelles and the Bosphorus. Эпоха правления в Турции Партии справедливости и развития: промежуточные итоги и прогнозы. (2002-2015), Москва, 2017, с. 102:

${ }_{35}$ Melis Alphan, Çılgın proje değil, felaket çılgınlı̆̆ı, (16. 12. 2013), https://www.hurriyet.com.tr/cilgin-projedegil-felaket-cilginligi-25367944.

${ }^{36}$ Kanal İstanbul Projesi’ni 2026 gibi tamamlamış olacağız, (13.01.2020),

https://www.finansgundem.com/haber/bakan-turhan-kanal-istanbulu-2026-gibi-tamamlamis-olacagiz/1462914.
} 
$\underline{\text { aciklanan-kanal-istanbul-projesi-2591192 }}$

Turkey plans new major waterway to bypass Bosporus, (27.04.2011). https://www.sandiegouniontribune.com/sdut-turkey-plans-newmajor-waterway-to-bypass-bosporus-2011apr27-story.html.

İstanbul'un 19 ilçesi adalı olacak! 6 köprü ile birbirine bağlanacak!, (24.01.2018). https://www.hurriyet.com.tr/ekonomi/istanbulun-19-ilcesi-adaliolacak-6-kopru-ile-birbirine-baglanacak-40719953

Kanal İstanbul Projesinin Kesit ve Boyutlar1. https://www.kanalistanbul.gov.tr/tr/hersey/kanal-istanbulprojesinin-kesit-ve-boyutlari

Y1llara

Göre

Karşılaştırma

Tablosu. https://atlantis.udhb.gov.tr/istatistik/gemi gecis.aspx.

Barış Şimşek, Boğaz'dan 13 kat daha güvenli. (03.02.2020). https://www.sabah.com.tr/galeri/ekonomi/bogazdan-13-kat-dahaguvenli

İnfografikler, https://www.kanalistanbul.gov.tr/tr/infografik

Kanal İstanbul Projesi’ni 2026 gibi tamamlamış olacağı, (13.01.2020), https://www.milliyet.com.tr/gundem/kanal-istanbul-nedirguzegahi-aciklanan-kanal-istanbul-projesi-2591192

Nüfus ve Yeni Yerleşim Alanı, https://www.kanalistanbul.gov.tr/tr/hersey/nufusve-yeni-yerlesim-alani.

Özetle Kanal İstanbul Projesi, (02.01.2020), https://www.milliyet.com.tr/gundem/ozetle-kanal-istanbul-projesikanal-istanbul-ihalesi-kanal-istanbul-maliyeti-ve-kanal-istanbulced-raporu-hakkinda-bilinmesi-gerekenler-6114038

Kanal İstanbul raporu, "193 sayfa" ile özetlenerek İBB meclisine sunuldu, (15.03.2020).

https://www.istanbultakipte.com/haberler/cevre/kanal-istanbulraporu-193-sayfa-ile-ozetlenerek-ibb-meclisine-sunuldu.html.

Kanal Istanbul projesi, çevresel etki değerlendirmesi raporu, Aralik, 2019, Bölüm 3-8

Канал Стамбул - будущий туристический центр Турции. http://fellowtraveler.ru/kanal-stambul-budushhij-turisticheskij-centr 
Sinan, Ulgen. Choppy Waters For Turkey's Latest Megaproject. (21.01.2020). https://www.bloomberg.com/opinion/articles/2020-01-21/canalistanbul-choppy-waters-for-erdogan-s-latest-megaproject.

South Korean SK plans to partake in Kanal Istanbul, (10.05.2018). https://www.dailysabah.com/business/2018/05/10/south-korean-skplans-to-partake-in-kanal-istanbul

Emin, Özgönül. Kanal İstanbul'a Panama modeli, (07.05.2017). https://www.sozcu.com.tr/2017/ekonomi/kanal-istanbula-panamamodeli-1835664/

Cemal, Gökçe. İstanbul Kanal Projesi Neden Yapılmamalıdır? Türkiye Mühendislik Haberleri, Sayı: 490 61/2016-2, s. 60-61.

Ertuğrul ,Günay. Canal Istanbul project casts doubts on Montreux Convention, (23.12.2019).

https://ahvalnews.com/montreux-convention/canal-istanbulproject-casts-doubts-montreux-convention

Dicle B., Özarslan. Uluslararası politika açısından Kanal İstanbul: 310 milyon insan için bir risk. (14.10.2018), https://t24.com.tr/haber/uluslararasi-politika-acisindan-kanalistanbul-310-milyon-insan-icin-bir-risk,722851.

Sena, Yaşar. Jeoloji mühendislerinden uyarı: 'Marmara'da sahil kalmaz', (23.01.2020).

https://www.cumhuriyet.com.tr/haber/jeoloji-muhendislerindenuyari-marmarada-sahil-kalmaz-1715791.

Kanal İstanbul ÇED raporu onaylandı! Sazlıdere Barajı kapatılıyor, (17.01.2020), https://www.kayabasimahallesi.com/haber/2950/kanal-istanbulced-raporu-onaylandi-sazlidere-baraji-kapatiliyor.html.

Эрдоган анонсировал тендер на проект канала «Стамбул» в обход Босфора, (08.03.2020). https://ria.ru/20200308/1568328983.html.

Габриелян, Айк. Турция: Стамбульский канал и Конвенция Монтрё, (28.02.2017). http://www.iimes.ru/?p=32948

Gabrielyan, Hayk. On the Construction of the Istanbul Canal in Turkey, (26.03.2018).

http://noravank.am/arm/articles/detail.php?ELEMENT_ID=16532. 
Ольга, Будник. Канал «Стамбул»: невозможно возможный проект, (20.12.2019), https://www.ukrinform.ru/rubrictechnology/2842117-kanal-stambul-nevozmozno-vozmoznyjproekt.html

Умбрасас, А.Р. Современное состояние и перспективы конвенции Монтрё 1936 г. о статусе проливов, Международный журнал прикладных наук и технологий «Integral» №3, 2019, с. 511-517.

Конвенция Монтрё о статусе проливов. Досье, https://tass.ru/info/1418303

Hilmi, Hacaloğlu. Kanal İstanbul Montrö Sözleşmesi’ni Tehdit Ediyor mu? (10.01.2020).

https://www.amerikaninsesi.com/a/kanal-istanbul-montrosozlesmesini-tehdit-ediyor-mu/5240735.html

Mehmet Ali Güller. Kanal İstanbul: NATO’ya Karadeniz yolu, (16.12.2019). http://cumhuriyet.com.tr/koseyazisi/1708425/kanal-istanbulnatoya-karadeniz-yolu.html

Jennifer Hattam. Turkish Prime Minister Erdoğan's 'Crazy Project' for Istanbul: Building a Second Strait, (30.04.2011), https://www.treehugger.com/corporate-responsibility/turkishprime-minister-erdoayans-crazy-project-for-istanbul-building-asecond-strait.html

Kanal Istanbul'dan 5 milyar dolar gelir beklentisi!, (18.05.2011). https://emlakkulisi.com/kanalistanbuldan-5-milyar-dolar-gelirbeklentisi/73548

Nazlı, Yüzbaşığlu. Dışişleri Bakanı Çavuşoğlu: Emekli büyükelçilerin Kanal İstanbul açıklaması siyasi bir deklarasyondur, (02.02.2020), https://www.aa.com.tr/tr/politika/disisleri-bakani-cavusogluemekli-buyukelcilerin-kanal-istanbul-aciklamasi-siyasi-birdeklarasyondur/1721885

Feargus, O’Sullivan. Could Istanbul's Protesters Halt Turkey's Controversial Canal Project? (04.06.2013), https://www.citylab.com/life/2013/06/could-istanbuls-protestershalt-turkeys-controversial-canal-project/5787/.

Эпоха правления в Турции Партии справедливости и развития: промежуточные итоги и прогнозы. (2002-2015), Москва, 2017, c. 102 
Melis, Alphan.Çılgın proje değil, felaket çılgınlı̆̆ı, (16. 12. 2013), https://www.hurriyet.com.tr/cilgin-proje-degil-felaket-cilginligi25367944.

Kanal İstanbul Projesi'ni 2026 gibi tamamlamış olacağız, (13.01.2020), https://www.finansgundem.com/haber/bakan-turhan-kanalistanbulu-2026-gibi-tamamlamis-olacagiz/1462914. 